\title{
鮮演の性具善悪説
}

\section{張文 良}

\section{はじめに}

性具善悪説といえば，一般には天台宗の説を思い浮かべがちであるが，実は華 厳教学にも類似した説がある。十一世紀, 遼で活躍した華厳学者, 鮮演の説はそ の一例である．鮮演は主著『華厳談玄抉択』において澄観の説を解釈する形で「如 来は性悪を断じない」という命題に対して自説を展開し, 性悪とはどんな意味で あるのか，また仏教思想の中でどのように位置付けられているのかを論じた。本 発表は華厳教学における性悪説を跡づけながら, 鮮演の性悪説の内容と特徴を解 明しょうとするものである。

\section{1. 華跾教学における性悪説}

一般に性具善悪説は天台教学に特有な説と見なされ，天台教学の思想的キー ワードの一つとして理解される.天台教学における性具善悪説は智顗に端を発し, 湛然などによってさらに敷衍された説である，その要点は以下の四点にまとめる ことができる．(1)善と悪にはそれぞれ性善・修善と性悪・修悪とがある．(2)修善・ 修悪は断じることができるが, 性善・性悪は断じることができない. (3)なぜなら 性悪・性善は善悪の法門として改めることはできない.したがって誰もこれを毀 すことができない. (4)故に䦐提であっても性善を断じることはできず，仏であっ ても性悪を断じることができない，智顗の説明に従えば, 天台教学における性具 善悪説の理論的基盤は, 一念具十界と善悪相資に求めることができる. 智顗の説 では，凡夫の一念はとりもなおさず十界を具えており，悪の性相があるからこそ 善の性相がありうるのである，悪とは善を成長させる資糧であり，諸々の悪を転 換させることよってはじめて善が生じるのである。

性具善悪説は智顗の天台教学において，はじめて体系化されたわけであるが， 他の宗派に類似した説がないわけではない。たとえば，法蔵は「発菩提心章」で 
「冈融俱徳門」を明かす際に,「一法法爾性善悪」といい, 性にはもとより善と悪 とが具わると主張している。 また善と悪は何かということについて，法蔵は『探 玄記』で「善というのは涅槃浄法であり, 悪というのは生死染法である」と規定 し，「この二つにはともに自性がなく，性において融摂している．故に平等であ るという」と主張している，つまり，性の次元においては，善と悪は互いに融摂 しあって，平等一味であるから，性には善と悪とが同時に具わっているとするの である。このような法蔵の主張は智顗の説ほど体系化しているわけではないが, それゆえにここにはさらに展開する余地が残されているともいえよう.

天台宗の説を受容しつつ，華厳教学の性悪説を打ち出したのは，華厳宗の四祖 とされる澄観である。

澄観は『華厳経疏』において『華厳経』の「唯心偈」を解釈する際に,

応云心仏与衆生, 体性皆無尽. 以妄体本真, 故亦無尽. 是以如来不断性悪. 亦猶閵提不 断性善. (T35.658c10-14)

心・仏・衆生は体性において，いずれも無尽であるというべきである．妄の体そのもの が真であるので（安も）無尽である．それゆえに如来は性悪を断じない．これはあたか も闈提が性善を断じないようなものである.

と述べている. 澄観は, 真も妄も真（如）を体としているので, 真のみならず妄 も本性として無尽であるといい，さらに真妄が無尽であるので如来には性悪があ り, 䦐提には性善があると主張するのである．さらに澄観は『演義鈔』において， このことについて次のように再解釈している.

是以如来下, 引例証此. 即涅槃経意. 天台用之. 以善悪二法, 同以真如而為其性. 若断 善性, 即断真如. 真不可断, 故云性善不可断也. 伀性即是真実之性, 真赛之性即第一義空, 如何可断. 性悪不断, 即妄法本真. 故無尽也. (T36.323c20-27)

「是以如来」以下は，例を引用してこの道理を証明する。これはすなわち『涅槃経』の 意である，天台宗はこれを用いている．善・悪という二法はいずれも真如をその性とし ている，もし善性を断じるならば，真如を断じることになる，真如を断じることができ ないので, 性善は断じることができない. 伀性は, とりもな执さず真実の性であり, 真 実の性は，とりもな拉さず第一義空であるので，どうして断じることができようか. 性 悪を断じることができないのは，とりもな拉さず妄法そのものが真実であるので, 妄法 も無尽であるからである.

ここで澄観は，最初に『涅槃経』に説かれている仏性の遍在性に基づいて善性 の遍在性を説くのである．仏性は真実の性であり，第一義空であるため，断じる ことができない，したがって閵提にも仏性があるとする，また，天台宗の説を取 
り入れて, 善性のみならず悪性も断じることができないと主張するにいたる.

澄観は天台宗の説を取り入れたが，その立場はかならずしも天台宗のそれと完 全に一致するわけではない．天台宗の性具善悪説はあくまでも十界互具説と結び 付いている，すなわち，十界のそれぞれが十界を具えていることを根拠にして， 仏界と地獄の相即を説くのである。そこに善悪の問題が加わり，仏には性悪があ り，地獄には性善があるという説が生まれたのである。これに対して，澄観はあ くまでも『涅槃経』に説かれる仏性説に基づいて，性善·性悪説を展開している. つまり, 仏性は第一義空であるため, 善は善として, 悪は悪として存在しつつ, いずれも空のもとに融摂しているため，性の次元においては，善も悪も不二とな る.そして，善悪不二であれば，性の次元において，如来であっても性悪を断じ ないという命題が成立可能となる，しかし，華厳教学においては，善悪とも真性 に依るとはいえ，真性に違すれば悪，真性に順ずれば善となるので，性が善と見 なされる傾向が強いのは事実である，そうすると，性の統一性・遍在性により衆 生に性善があるという結論を導き出すことは容易であるが，仏に性悪があるとい う結論に到達する必然性はなくなってしまう.

このことを意識してか, 澄観は性の根源性・超越性を論証するために, 一応, 天台宗の説を取り入れているものの，踏み込んでこれを論じず，かえってそれを 否定するかのような学説を展開している．澄観は『演義鈔』で「聖心に即して凡 心を見る」という句を解釈する際に，

即聖心而見凡心. 如湿中見波。故如来不断性悪. ……約有不壊相，但明凡即同聖，以 即真故. 而聖不同凡, 無煩㮸故. ……説凡即是仏, 於凡有益. 仏即是凡, 令人妄解. 是故但云即凡心而見仏心耳. (T36.8b1-10)

聖心に即して凡心を見る．あたかも湿の中に波が見られるようなものである．故に如来 は性悪を断じない，……ま，壊れない相があるという立場からいうと，ただ凡夫がと りもなおさず聖と同じであるだけを明らかにする。（なぜなら，妄が）真に即するから である．聖は凡夫と同じではない（なぜなら，聖に）煩悩がないからである．……さ らにまた，凡夫がとりもなおさず仏であるというならば，凡夫に有益であるが，仏がと りもなおさず凡夫であるというならば，人々が誤解しやすい，それゅえに，ただ「凡心 に即して聖心を見る」というだけである。

と述べている，これを見ると，澄観は如来に性悪があることを認めているが，こ れは性の立場から相を見る場合に限る結論であるとし，相の立場から言えば仏は 煩悩を断じるから，悪がないはずであると主張していることがわかる.

仏には性悪があるが，現実的には仏に悪の行為がない，ということについて， 
智顗は「性悪」と「修悪」の概念を提示しそれを説明している，智顗は，仏は性 悪を断じないものの，よく悪の本質を洞察するため，悪において自在であると主 張する。つまり，広く諸悪の法門を用いて衆生を救済するけれども，一切に悪に 染まらず，「修悪」を起こさないとする．澄観は「性悪」「修悪」という概念こ そ用いてはいないものの, 聖者には煩悩がないとし, もしたとえ聖者に悪の行為 があったとしても，衆生を救済するためにわざと悪の姿を現わしていると主張す るのである。

\section{2。鮮演における性悪説}

『華厳経談玄抉択』は，鮮演による澄観の『華厳経疏』の玄談部分に対する注 釈書である．鮮演はその中で「如来は性悪を断じない」という命題を再解釈する 形で性悪説を展開している。

鮮演の性悪説の一番の特徵は, 教判説に関連づけて性悪説を説くところである. 鮮演は法蔵の五教教判（小教・始教・終教・頓教・円教）を継承し, 五教のそれぞ れに如来性悪の義があると主張している，たとえば，小教においては，如来の性 悪に，仏前の十五界が有漏であると，仏の示現であるとの二意があるとする．ま た，大乗始教における如来性㤟の意味については，二義があると述べている，つ まり，一義には，性善も性悪も同じく真如を性として断じることができないので， 如来にも性悪があるという説明であり，二義にはやはり如来は衆生を教化するた めにいろいろな姿を示現し，その中に悪の姿をも含む，という意味である.

さらに，頓教における性悪の意味について，「(如来は) 相としての悪がもとよ り尽きているので, 改めて断じることを待たない（如来は）性としての悪がもと より現れているので, 断じる対象ではない.（悪相本尽, 更不待断. 悪性本現, 非所 断故)」(Z8.6b7-8）という，円教の場合，「性にかなう悪は，鏡に映された火のよ うに，現れてくるものの，単に空である．断じる対象ではない，称性之悪, 如鏡 中火, 現而常虚. 非所断故.)」と主張している.

華厳の五教判において, 円教は仏の最高の教理と位置づけられるが, 如来の性 悪説に限っていえば，終教の説に，いわば真如縁起の立場からの説に当てはまる と，鮮演は主張している。終教の説について，

終教亦有二義. 一云昔日真如随縁以作説法. 今至果位, 無明既断, 悪相雖無, 随縁真性 仍存故。……云悪具二義. 一不壊相異真義（当縁生相有也）。二称性即真義（当無性 体空義). 今据後義, 故云不断. (X8, p6, b2-7) 
終教も二義がある.一に, 昔, 真如が随縁して（仏が）説法を施した．いま，果位に至 ると，無明が既に断じて悪相がなくなったものの，随緣する真性が相変わらず存在する

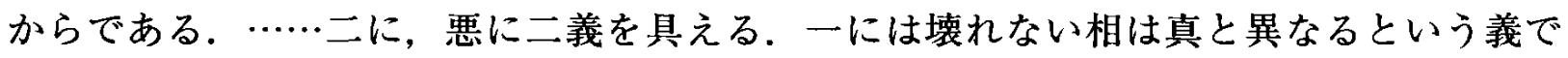
ある（縁生相有に当たる），二には性にかなうのはとりもなおさず真であるという義で ある（無性体空に当たる），いま，第二の義によるが故に（如来は性悪を）断じないと いう.

と述べ，真如が随縁しても空性が変わらないので性としての悪を断じないと主張 する.ここでは，鮮演は澄観の思想を受け継ぎ，真妄論に関連づけて悪を論じて いるが，「悪」を「妄」ではなく「真」そのものに当てるのは鮮演の特徴である. つまり，「悪」に「縁生」と「体空」という二義があるが，如来における性悪は やはり「体空」あるいは「即真」に当たると主張している。

前述したように, 澄観は『涅槃経』の仏性説を意識しながら性悪説を展開した が，鮮演もこの説を継承して如来の善仏性と性悪との矛盾を調和しようとした。 『涅槃経』の仏性説といえば，最も特徽的なのは，「迦葉菩薩品」に説かれる四種 の仏性説であろう。その中には善仏性がある。これは善根人（菩薩）にしかあり えないといわれている。言い換えれば，善根人には善性があるが不善性がない。 では，善根人でさえ善性のみで不善性がないのに，どうして如来に性悪があるの だろうか. 鮮演はこれについて，

若爾, 何故涅槃経説如来無不善仏性. 答曰. 彼据以理従事即無. 此据摂事従理不断. 又 彼約現在為名. 此据過去立号. 故彼此文不相違背。(X8,p6,b13-16)

もしそうであれば，なぜ『涅槃経』において如来に不善仏性がないと説かれているのか. 答える.『涅槃経』は理をもって事に従わせることによって，如来に不善仏性がないと いうが,『華厳経疏』は事を摃して理に従わせることによって，如来は性悪を断じない と主張する．さらにまた，『涅槃経』は（善根人の）現在（果位）の状況によって（善 根人と）名づけるが,『華厳経疏』は（如来の）過去（因位）の状況によって（如来の） 号を立てるのである，故に両者の文は互いに矛盾するわけではない.

と述べている。つまり, 鮮演はここで「理」と「事」,「因」と「果」という対概 念をもって善性と性悪との対立を解消しようとしている.「事」の立場から如来 の仏性を見るならば，やはりただ善性のみがあり不善性はないが，「理」の立場 から見れば，如来にさえ性としての悪があるはずであるとする。これは華厳の理 事無碍の立場から『涅槃経』の説と『華厳経疏』の説とを調和させる試みである. さらにまた, 鮮演は性悪を如来の過去（因位）のものとし, 善性を如来の現在（果 位）のものとすることによって性悪と善性の調和を図ったが，これは華厳の教理 とあまり関係がなく，鮮演の独特な説であるといえよう。 
前述したように，澄観は如来の性悪を認めても，善知識に現れている悪を真の 悪として認めず，衆生を教化するための方便にすぎないと見なしている．一方， 澄観のこのような立場を継承した鮮演には，さらに進めて悪の価值を積極的に受 け止めようとする姿勢が見られる。つまり，煩悩が単に方便だけではなく菩薩の 実践において必要不可欠な要素であり，煩悩を離れると，衆生救済が不可能にな ると主張するのである，たとえば，彼は『円覚経』に説かれる「滅病」を批判し て，真の菩薩は「動に離れずに静を求め，惑を怖れずに衆生を救済する」（不釋 動以求静, 不怖惑而度生）という。煩悩を離れ静寂を求めるのは, 二乗のやり方で 決して菩薩の実践ではないとする，その説が成り立つのは，その底流に，「妄念 はとりもな扮さず真であり, 領矄はもともと道である」(妄念即真, 貪瞁本道) と いう認識があるからである.

\section{3．鮮演の性悪説の特徴}

智顗が「性としての善悪は，単に善悪の法門にすぎない」というように, 性善・ 性悪は，善業・悪業（善因・悪因）の意味ではなく，善の性質・悪の性質の意味 である．善業・悪業は現象的・相対的な存在であるのに対して，性善・性悪は世 間の善悪を捨離・超越した存在であるといえよう。このような存在は天台宗にお いては真如と名づけられており，澄観においては仏性（第一義空）と名づけられ ているが，鮮演においては善悪の「理」として理解されている．彼らはそれぞれ に依据する理論が相違するが,いずれも如来に性悪があると認めている．さらに， 如来の性悪と衆生を救済するための悪法門とを区別し，両者が矛盾しないと主張 する点も一致している。

澄観は天台の性悪説を取り入れたが，主に仏性の空性を説明するための一例と してこれを挙げただけであり，積極的にこれを展開する意図は見られない。これ に対して，鮮演は華厳教学の五教判に関連づけて如来性悪説の様々な意味を提示 し，「縁起」・「性空」，「理」・「事」といった概念によって華撖の立場を明らかに する.

鮮演の思想において際だつ特徵は『円覚経』の本覚思想の影響であるといえよ う。彼は『華㛜経談玄抉択』において『円覚経』の文を多く引用しながら自説を 展開し,衆生にはもともと本覚があるという『円覚経』の立場を受け入れている. このような鮮演の本覚思想は彼の性悪説にどのような影響を与えたのであろう か．鮮演は『華厳経』に出る「大塔廟」の意味を解釈する際に，これを「宗旨に 
㷌するところ（帰宗之所）」と捉え, 諸仏はいずれも「法界・本覚・真性」に依据 すると主張する。当然, 諸仏の存在根拠が「法界」・「本覚」·「真性」である以上, 性悪が存する余地はないのではないか，という疑問が生じるが，これについて鮮 演は十分に説明していない.

さらに，衆生の本覚と悪業との矛盾についても，鮮演は苦慮していたようであ る、『華嵈経』に, 地獄天子が『華厳経』を聴聞するため成仏の種子を薫成した という話がある。鮮演はこれを解釈する際に，地獄天子は本覚を因とし聞経を縁 としているから，成仏の種子を薰成したと言う。しかし，もしそうであれば， る人が殺盗などの話を聞くと，同様に本覚を因として悪の種子を薫成してしまう のではないか，という疑問が生じる，本覚はただ善種のみの因ではなく，悪種の 因でもあるはずである。この難問に対して，鮮演は，同一の因（本覚）が同様に 二種の種子（成仏の種子と地獄の種子）を薫成するのは, 縁が相違しているからで あるといい，またこれが「実は不思議なことである」と解釈するにとどまって いる.

\section{4. 結び}

鮮演は澄観の立場を継承しながら，「如来は性悪を断じない」という命題を教 判論に関連づけて，その意味をそれぞれの角度から分析した。鮮演の解釈で最も 特筆すべきは，この命題を円教ではなく大乗終教に配当して解釈していることで ある．終教の真如縁起の原理に基ついて解釈すると，真如が随縁しても真性ある いは空性が変わらないため, 如来は性悪を断じない, と鮮演は主張する。しかし, 『円覚経』の本覚思想を受容したために，如来だけではなく，衆生において本覚 の因と悪の業とがどのように両立するかという問題が生じてしまった。これに对 して鮮演は十分に説明しきれなかったようである。

(本研究は, 2009 年度科学研究費補助金（特別研究員奨励費）による研究成果の一部で ある)

〈キーワード〉 鮮演, 性畫説, 華厳

（中国人民大学仏教与宗教学理論研究所） 